\title{
13
}

\section{GREEN ECONOMY PERFORMANCE OF ENVIRONMENTAL INITIATIVES IN LATIN AMERICA AND THE CARIBBEAN}

\author{
Ronal Gainza and Simon Lobach
}

\section{Introduction}

A major outcome of the 2012 United Nations Conference on Sustainable Development (Rio+20), is the international community's recognition that a green economy is a tool for achieving sustainable development. Countries attending the conference emphasized that any green economy intervention should simultaneously contribute to the following three goals: sustaining economic growth, enhancing social inclusion and maintaining the healthy functioning of the earth's ecosystems (United Nations Environmental Programme [UNEP] 2011; United Nations 2012). The Green Economy Report produced by UNEP (2011) asserts that the transition towards a green economy contributes to achieving sustainable development. The Sustainable Development Goals (SDGs) that countries adopted in 2015 speak to these same objectives.

As suggested by Strange and Bayley (2008), assessing progress on sustainability has to identify not only the economic, environmental and social impacts but also the synergies and trade-offs across the three pillars of sustainable development. By definition, a green economy has to address the complex connections and interdependence of these three pillars, with the aim of avoiding the trade-offs that traditional sustainable development policies can imply. The key assumption of the green economy approach is the idea that initiatives that help achieve outcomes in one pillar do not need to lead to trade-offs with other pillar objectives. Consistent with this, we argue that any set of indicators for green economy initiatives must measure and give equal weight to economic growth, social equity and ecosystem protection.

UNEP has been at the forefront of promoting a green economy and it is providing policy advice, technical assistance and capacity building to governments around the world. One initial gap was the absence of a measurement approach. Efforts to introduce metrics to evaluate the transition towards a green economy have recently 
been initiated. Organisation for Economic Co-operation and Development (OECD; 2011) proposes indicators to monitor progress towards green growth; the Global Green Growth Institute launched in 2019 the Green Growth Index, which measures country performance in four green growth dimensions - efficient and sustainable resource use, natural capital protection, green economic opportunities and social inclusion (Acosta et al., 2019), and PAGE (2017) developed the Green Economy Progress Measurement Framework to help countries evaluate their overall progress towards an Inclusive Green Economy. In 2020, UN-Environment has developed the Inclusive Green Economy Policy Review methodology (UNEP, 2020), which assesses the coherence and effectiveness of existing policies in fostering an Inclusive Green Economy transition.

The scope of most existing measurement frameworks is at the country or subnational level ${ }^{1}$ and gives little space to comprehensively and simultaneously measure stand-alone initiatives' contributions to green economy and the SDGs. If the green economy is to be viable and successful, then measurement frameworks need to also identify potential trade-offs and win-win-win options between the three pillars of sustainable development.

This chapter proposes a methodology to fill this gap. Acknowledging that indicators traditionally require a lot of system- and measurement-related work, we develop a system of assessment that is quick and helps policy makers and others assess whether so-called green interventions actually meet the objectives of a green economy. We develop criteria built on existing indicator frameworks and a green performance grading system. These criteria help measuring the social, environmental and economic performance of environmental initiatives, and informing about their contribution to the SDGs. We then test this framework by applying it to four environmental initiatives (located in Latin America and the Caribbean).

The remainder of this chapter is organized as follows: we first describe our proposed methodological framework for assessing the green economy performance of environmental initiatives. Then, we present the four environmental initiatives. Finally, we discuss the major results from our analysis, including enabling conditions and financing as well as main challenges and opportunities.

\section{Methodological framework for assessing green economy performance of environmental initiatives in developing countries}

A green economy has three pillars of sustainable development: ecosystem protection, economic growth and social equity.

\section{Evidence-based criteria}

A checklist that examines initiatives with regard to their green economy performance must address all these criteria. In the following, the three pillars are briefly described. 


\section{Ecosystem protection}

In a green economy, natural capital must be used efficiently while reducing environmental risk so that resource use is sustainable and ecological scarcities are alleviated. ${ }^{2}$ Based on this, this chapter proposes the following proxy indicators to assess the performance of green economy initiatives in developing countries with respect to environmental sustainability in four sectors:

Forest: forest cover stays the same or increases (contributes to SDG 15);

Freshwater: watersheds or water surfaces remain or come under effective protection (contributes to SDG 6);

Renewable energy technologies: cleaner technologies are introduced for improving access to clean energy and energy efficiency as well as reducing GHG (contributes to SDGs 7 and 13); and

Cities: the public transport network stays the same or increases; energy demand is met by green sources; green areas in urban areas increase or remain the same; food is increasingly produced in urban/peri-urban areas; the stock of green buildings and sustainable infrastructure in general increase; and materials are preferably locally sourced and where appropriate they can be composted, recycled and reused in order to reduce waste or avoid its increase (contributes to SDGs 6,11 and SDG 12).

\section{Economic growth}

Green economy initiatives must promote and deliver economic growth over time. Gross domestic product growth is traditionally regarded as the single most important indicator for economic growth and development. Besides assessing the impact of specific green economy initiatives on the local economy, this chapter also proposes that public and private investments that support the initiative can be used as proxy indicators for gross domestic product growth. These indicators contribute to SGDs 8 and 17.

\section{Social equity}

Green economy initiatives must improve people's lives and well-being and promote social equity and health benefits. Based on the system of indicators developed by Villatoro and Feres (2007) to monitor social cohesion in Latin America, this chapter proposes the following proxy indicators to assess social equity:

Poverty reduction (contributes to SDG 1)

- People's income increases or at least does not diminish; and

- Additional benefits are received by vulnerable groups in society.

Employment (contributes to SDG 8)

- Jobs are created or at least remain the same. 
Social protection (contributes to SDG 1)

- $\quad$ People are incorporated into social protection schemes.

Education (contributes to SDG 1)

- More people are educated or trained through green economy initiatives.

Health (contributes to SDG 3)

- People live in improved environments (i.e. indoor and outdoor pollution is reduced or at least does not increase);

- People have healthier lifestyles.

Consumption and access to basic services (contribute to SDG 1)

- Increased access to basic services including access to safe water and sewerage;

- Increased access to social infrastructure (e.g. supermarkets, hospitals, public transport).

\section{Grade system to assess green performance}

Through the assessment of environmental initiatives' performance levels, this chapter provides a framework for determining whether a given initiative can be classified as a green economy initiative (see Table 13.1). ${ }^{3}$

\section{Environmental initiatives in Latin America and the Caribbean}

\section{Forest: national forestry financing fund in Costa Rica}

\section{Background}

Costa Rica has an estimated forest cover of 2.6 million hectares, which represents $51 \%$ of its national territory (Food and Agriculture Organization [FAO] 2011). The country suffered extensive deforestation in the beginning of the second half of the 20th century. Vast stretches of rainforest were burned and converted into cattle lands and for agriculture use. Between 1986 and 1991, the country lost 4.2\% of its remaining forest cover per year (Daniels et al.2010), and by 1990 its forest cover was only of 1.6 million hectares (Madrigal, Alpízar and Otárola 2006).

Beginning in the late 1970s, Costa Rica introduced forestry incentives with the aim of enhancing the forest cover. These included favourable credit conditions, tradable tax vouchers and subsidies (Daniels et al.2010). As a result of a third loan negotiation process with the World Bank, general subsidies (including forestry subsidies) were abolished and the forestry sector started exerting pressure on the government to receive support. 
TABLE 13.1 Grading System to Assess the 'Green' level of Performance of Environmental

\begin{tabular}{|c|c|c|c|}
\hline Performance & Ecosystem protection & Social equity & Economic growth \\
\hline$d$ & $\begin{array}{l}\text { It has positive } \\
\text { externalities on } \\
\text { the environment } \\
\text { (i.e. reducing } \\
\text { environmental } \\
\text { risks and ecological } \\
\text { scarcities, preserving } \\
\text { natural capital). }\end{array}$ & $\begin{array}{l}\text { It significantly contributes } \\
\text { to enhancing social } \\
\text { equity and reducing } \\
\text { poverty, and/or } \\
\text { improves the human } \\
\text { well-being of all social } \\
\text { groups involved. }\end{array}$ & $\begin{array}{l}\text { It has a significant } \\
\text { positive spill- } \\
\text { over effect on the } \\
\text { overall economy } \\
\text { at the national or } \\
\text { regional level (i.e. } \\
\text { it stimulates steady } \\
\text { economic growth). }\end{array}$ \\
\hline Medium & $\begin{array}{l}\text { It is possible to measure } \\
\text { a reduction or halt } \\
\text { in environmental } \\
\text { degradation. }\end{array}$ & $\begin{array}{l}\text { It contributes to reversing/ } \\
\text { avoiding social } \\
\text { inequalities and/or } \\
\text { enables more than one } \\
\text { social group to receive } \\
\text { direct or indirect } \\
\text { benefits. }\end{array}$ & $\begin{array}{l}\text { It has a positive impact } \\
\text { on the overall } \\
\text { economy. }\end{array}$ \\
\hline Poor & $\begin{array}{l}\text { Though it is expected } \\
\text { to have a positive } \\
\text { impact on the } \\
\text { environment, there is } \\
\text { no reliable evidence } \\
\text { that supports it, and/ } \\
\text { or the impact on } \\
\text { the environment is } \\
\text { negligible or neutral. }\end{array}$ & $\begin{array}{l}\text { It benefits/excludes } \\
\text { specific social groups } \\
\text { or social benefits are } \\
\text { minimal, or the impact } \\
\text { is neutral. }\end{array}$ & $\begin{array}{l}\text { No impact on local or } \\
\text { national economic } \\
\text { growth can be } \\
\text { observed. }\end{array}$ \\
\hline Negative & $\begin{array}{l}\text { It has adverse effects on } \\
\text { the environment. }\end{array}$ & It deepens so & $\begin{array}{l}\text { It causes economic } \\
\text { losses. }\end{array}$ \\
\hline
\end{tabular}

\section{The initiative}

In response to this worsening situation, the government of Costa Rica established the National Forestry Financing Fund (FONAFIFO) ${ }^{4}$ to complement existing forestry legislation. It is used to compensate the opportunity costs borne by private landholders of forests affected by legislation that prohibits land use change. FONAFIFO collects funds to support the payment for ecosystem services (PES) programme. Small and medium landholders may participate through reforestation, protection of existing forest, natural forest regeneration and agroforestry systems (see Table 13.2 for a list of modalities of compensation).

\section{Functioning}

FONAFIFO receives funding from four different sources. First, it receives public funds (the government assigns $3.5 \%$ of its fuel tax revenue to the fund). This financing mechanism is based on the 'polluter pays' principle. Second, FONAFIFO makes 
TABLE 13.2 Modalities of Compensation in the PES, Costa Rica

\begin{tabular}{|c|c|c|c|c|}
\hline Modalities & Legal status & Criteria & $\begin{array}{l}\text { Current payments } \\
\text { (\$2011) }\end{array}$ & $\begin{array}{l}\text { Contracted } \\
\text { (hectares) }^{a}\end{array}$ \\
\hline $\begin{array}{l}\text { Forest } \\
\quad \text { protection }\end{array}$ & $\begin{array}{l}\text { Forest Law } 7575 \\
\text { started in } 1997, \\
\text { applicable till } \\
\text { today }\end{array}$ & $\begin{array}{l}\text { 2-300 hectares } \\
\text { enrolled, } \\
\text { up to } 600 \\
\text { hectares within } \\
\text { indigenous areas }\end{array}$ & $\begin{array}{l}\text { 64/hectares per } \\
\text { year for five- } \\
\text { year period; } \\
\text { renewable }\end{array}$ & 710,095 \\
\hline Reforestation & $\begin{array}{l}\text { Forest Law } 7575 \\
\text { started in } 1997, \\
\text { applicable till } \\
\text { today }\end{array}$ & $\begin{array}{l}\text { Between } 1 \text { and } \\
300 \text { hectares } \\
\text { enrolled }\end{array}$ & $\begin{array}{l}816 / \text { hectares over } \\
10 \text {-year period }\end{array}$ & 49,039 \\
\hline $\begin{array}{l}\text { Natural forest } \\
\text { regeneration }\end{array}$ & 2005 to present & $\begin{array}{l}\text { Minimum of } 2 \\
\text { hectares }\end{array}$ & $\begin{array}{l}41 / \text { hectares per } \\
\text { year for five- } \\
\text { year period; } \\
\text { renewable }\end{array}$ & 5,469 \\
\hline $\begin{array}{l}\text { Agroforestry } \\
\text { systems }\end{array}$ & 2003 to present & $\begin{array}{l}350 \text { to } 3,500 \text { trees } \\
\text { per participant; } \\
\text { up to } 336,000 \\
\text { trees per } \\
\text { joint project, } \\
\text { cooperative } \\
\text { or indigenous } \\
\text { reserve; specific } \\
\text { requirements } \\
\text { per hectares }\end{array}$ & $\begin{array}{l}1.30 \text { per tree up } \\
\text { to } 3,500 \text { trees, } \\
\text { over three-year } \\
\text { period }\end{array}$ & $3,508,873^{b}$ \\
\hline $\begin{array}{l}\text { Forest } \\
\text { management }\end{array}$ & $\begin{array}{l}\text { Forest Law 7,575 } \\
\text { in } 1997 \text {, until } \\
2002\end{array}$ & $\begin{array}{l}\text { Criteria } \\
\text { determined by } \\
\text { conservation } \\
\text { area }\end{array}$ & $\begin{array}{l}\text { About } \$ 343 \text { per } \\
\text { hectares, over } \\
\text { five-year period }\end{array}$ & 28,375 \\
\hline
\end{tabular}

Sources: Compiled from Daniels et al. (2010); Madrigal et al. (2006); FONAFIFO website (2012).

${ }^{a}$ Contracted hectares as of 31 May 2011.

b Trees.

voluntary agreements with specific enterprises, which allocate funds for conservation activities in areas of their interest. Third, international organizations provide grants and loans for the provision of global public goods. Fourth, FONAFIFO sells Certificates of Environmental Services to individual investors, private companies and public organizations interested in investing in legally recognized environmental services. Investors can select the forest area of their interest, and the price per hectare will vary depending on the location and features of the area. This is not a trade system, since certificates are not exchangeable among investors. The main motivation for companies to invest is a desire to enhance their corporate image. The government creates an additional incentive, as these investments are tax deductible (see Table 13.3). 
TABLE 13.3 Cumulative Contributions to FONAFIFO from 1998 to June 2011

\begin{tabular}{ll}
\hline Contributors & Cumulative contribution (million of \$2011) \\
\hline Public Financing & \\
$3.5 \%$ of collected fuel tax revenues & 121.74 \\
$\begin{array}{l}\text { Public-private agreements } \\
\text { Compañía Nacional de Fuerza } \gamma \text { Luz }\end{array}$ & $3.77 /$ to protect $11,900 \mathrm{ha}^{\mathrm{a}}$ \\
$\begin{array}{l}\text { Florida Ice and Farm and Empresa Servicios } \\
\quad \text { Públicos de Heredia }\end{array}$ & $0.15 /$ to protect $1,000 \mathrm{ha}^{\mathrm{b}}$ \\
Hydroelectric enterprises & $0.42 /$ to protect $5,711 \mathrm{ha}^{\mathrm{c}}$ \\
International financing & $57.37^{\mathrm{d}} /$ to protect 137,033 hectares of forest/ \\
Ecomercados & enhance participation of women and \\
& indigenous communities \\
Kfw & $11,606,677.29$ (grant)/ to protect 74,000 \\
& hectares for seven years \\
Certificates of Environmental Servicese & 0.43 \\
Total & 195.49 \\
\hline
\end{tabular}

Source: FONAFIFO (2011); Madrigal et al. (2006).

${ }^{a}$ Compañía Nacional de Fuerza y Luz pays $\$ 40 /$ hectares for a period of ten years.

b Florida Ice and Farm paid $\$ 45 /$ hectares from 2001 to 2007, and Públicos de Heredia has contributed $\$ 22 /$ hectares.

c Two hydroelectric enterprises have signed agreements with FONAFIFO. Energía Global paid \$10/ hectares between 1997 and 2002 and $\$ 12$ /hectares ever since. Hidroelectrica platanar pays \$15/ hectares to FONAFIFO for the areas which are already under the PES and $\$ 30 /$ hectares directly to landholders who are outside the PES due to a lack of funds and/or because they do not meet the requirements.

${ }^{\mathrm{d}}$ Loan of about $\$ 32.8$ million from the World Bank, a grant of about $\$ 8.0$ million from the Global Environment Facility (GEF), and $\$ 8.6$ million from the Costa Rican government.

${ }^{\mathrm{e}}$ At the time of writing, around 40 enterprises have acquired Certificates of Environmental Services.

\section{Freshwater: water protection fund, Quito, Ecuador}

\section{Background}

The availability of water for the Metropolitan District of Quito (approximately 2.3 million inhabitants), depends on the conservation of protected areas upstream. Of the district's water supply, $80 \%$ originates in two ecological reserves, the CayambeCoca (4,000,000 hectares) and the Antisana (120,000 hectares), both of which are national parks managed by the Ministry of Environment (UNEP 2010). Although these ecological reserves are formally protected for conservation, their ecological balance is menaced by unregulated activities, such as unsustainable agricultural practices. This results in degradation of water quality, which further affects Quito's water supply. Unfortunately, the lack of resources for the operation and protection of the reserves threatens the long-term conservation of these vital ecosystems and the water services they provide (Echavarria and Arroyo 2002). 


\section{The initiative}

In 1995, the Fundación Antisana carried out a study supported by the United States Agency for International Development (USAID), to design sustainable management plans for the ecological reserves upstream. As a result of this study, the Fund for Water Protection (FONAG) was established in 2000 as an economic instrument to support conservation efforts that were underway. Two other conditions that enabled the creation of FONAG were the political will of local decision makers and the change in the law governing public financing in 1999, which allowed public organizations to assign resources to a private mechanism (Echavarria and Arroyo 2002).

\section{Functioning}

FONAG is an economic-financial mechanism that is mandated to operate for eighty years in the form of a private mercantile trust. This trust fund under FONAG collects funding, in principle, from water users who, in turn, can become members of its board and determine FONAG's policies and strategies. Voting power depends on the amount of resources provided to the fund. Furthermore, constituents can appoint the members of the Technical Advisory Committee, which assists in defining and monitoring programmes and projects.

The current constituents of FONAG are the Municipal Water and Sewerage Authority of Quito, the Nature Conservancy, the Electric Utility of Quito, Cervecería Nacional, Swiss Development Cooperation and the Tesalia Springs Company. (FONAG 2013). The initiative also accepts additional funds from other organizations to co-finance specific programmes and projects. However, these additional resources are not allocated in the trust fund and co-financier organizations are not member of FONAG's Board. See Table 13.4 for details about the main contributions to the fund by constituents and other participating organizations as of 2011 .

The Technical Secretariat reviews the mechanism's financial performance, ensures project implementation and supervises the distribution of investments. Enlaces Funds, a private bank, is the financial manager of the trust fund (Echavarria and Arroyo 2002). Its main mission is to enhance the fund's profits through stock market investments (Cisneros and Lloret 2008). Only the profits of this trust fund are allocated to co-finance (along with national and international institutions) programmes and projects addressed to undertake upstream watershed protection activities, including reforestation, watershed management, environmental education, waste management and surveillance and monitoring (Echavarria and Arroyo 2002).

By rule, the trust fund under FONAG cannot provide more than a quarter of a project's total funding (Cisneros and Lloret 2008). From 2005 to 2009, for each dollar invested by FONAG in projects and programmes, the counterpart organizations contributed up to $\$ 4$ (FONAG 2011). Once a year, the fund reports to the government, and this information is made available to the public. Local-level implementing organizations and volunteers from local communities undertake watershed protection activities. 
TABLE 13.4 Contributions to FONAG by Constituents and Donors

\begin{tabular}{|c|c|}
\hline Contributors & Contribution/goals \\
\hline \multicolumn{2}{|l|}{ Constituents } \\
\hline $\begin{array}{l}\text { Municipal Water and Sewerage } \\
\text { Authority of Quito }\end{array}$ & $\begin{array}{l}\$ 20,000 \text { as capital seed and } 1 \% \text { drinking water sales } \\
\text { per year }\end{array}$ \\
\hline The Nature Conservancy & $\begin{array}{l}\$ 1,000 \text { as seed capital and } \$ 145,000 \text { as technical } \\
\text { assistance and support }\end{array}$ \\
\hline Electric Utility of Quito & $\$ 45,000$ per year \\
\hline Cervecería nacional & $\$ 6,000$ per year \\
\hline Swiss Development Cooperation & $\$ 30,000$ as one-off payment \\
\hline Tesalia Springs Co. & $\$ 7,000$ \\
\hline \multicolumn{2}{|l|}{ Co-financiers of programmes and projects } \\
\hline USAID & $\begin{array}{l}\text { \$3 million (2007-2012), institutional strengthening, } \\
\text { environmental education, surveillance, monitoring } \\
\text { and communication activities }\end{array}$ \\
\hline $\begin{array}{l}\text { Dutch Entrepeneurial Development } \\
\text { Bank (FMO) - Inter-American } \\
\text { Development Bank }\end{array}$ & $\begin{array}{l}\$ 140,000 \text { (2006-2010) development of water } \\
\text { management programmes }\end{array}$ \\
\hline $\begin{array}{l}\text { Deutsche Gesellschaft für } \\
\text { Internationale Zusammenarbeit } \\
\text { (GIZ) }\end{array}$ & Capacity building on watersheds management \\
\hline $\begin{array}{l}\text { Environmental Systems Research } \\
\text { Institute }\end{array}$ & $\begin{array}{l}\text { In-kind payment (i.e. software, technical books on } \\
\text { geographic information systems) }\end{array}$ \\
\hline Corporation 'Vida para Quito’^ & Reforestation programmes \\
\hline
\end{tabular}

Sources: FONAG website; USAID website; IDB (2006);Vida para Quito website.

* The Vida para Quito foundation is a non-profit organization subordinate to the Municipality of Quito. Its main goal is to carry out activities to protect and preserve the environment. Natural and legal persons may voluntarily make donations up to $25 \%$ of the amount of their income tax.

So far, there has not been any direct monetary compensation to farmers for taking part in protection activities. Nevertheless, FONAG has recently co-financed studies that assess and propose the implementation of PES programmes that might compensate farmers for carrying out reforestation activities.

\section{Renewable energy: solar water heaters in Barbados}

\section{Background}

Barbados' large potential for solar energy stems from its high solar endowment. Nevertheless, Barbados relies on imported refined fuels to meet nearly all (about 95\%) its power and transport needs. In 1999, Barbados imported more than 2 million barrels of petroleum products (Headley 2001). Less than 15\% of the refined product comes from domestic oil production. Electricity demand in the domestic and commercial sectors has grown recently at an average annual rate of more the $4 \%$. In 2003, total annual electricity consumption was about 735 gigawatt hours or almost 2,700 kilowatt hours per capita, one of the highest rates in the Caribbean 
region (Perlack and Hinds 2003). The government of Barbados has been advocating for renewable sources of energy, notably by expanding the use of solar water heaters. This policy has become the best example of the exploitation of a renewable energy technology in the Caribbean.

\section{The initiative}

Solar water heater policy in Barbados seeks to reduce energy consumer costs, stimulate the local market (including manufacturers and suppliers), reduce Barbados' dependency on imported fossil fuels and enhance the country's energy security. It has been led mainly through a set of fiscal policies. The first policy, adopted in 1974, suspended import duties on raw materials needed to manufacture the heaters, and introduced a $30 \%$ consumption tax on electric water heaters. Perlack and Hinds (2003) estimate that the effect of the duty-free importation of raw materials lowered installed costs by about $\$ 100$ per solar water heater. Between 1980 and 1993, homeowners were allowed to deduct the full cost of solar water heater installation, up to a maximum of $\$ 1,750$ per year. From 1996, this deduction was reintroduced and extended to repairs, renovations, energy or water saving devices and water storage tanks.

Table 13.5 shows the estimated payback periods for domestic solar water heaters in Barbados. The investment payback periods are short, particularly for households having an income of more than $\$ 12,000$.

\section{Cities: sustainable urban planning in Curitiba, Brazil}

\section{Background}

The processes of urbanization and internal migration in Brazil have caused problems such as pollution, traffic congestion, disappearance of public and green spaces, informal housing settlements and socio-economic ruptures in most of the country's urban

TABLE 13.5 Estimated Payback Periods for Domestic Solar Water Heaters, Barbados

\begin{tabular}{|c|c|c|c|c|c|}
\hline \multirow[t]{2}{*}{ Parameters } & & \multicolumn{4}{|c|}{ Solar water heater size (gallons) } \\
\hline & & 40 & 52 & 66 & 80 \\
\hline Installed cost (US\$2011) & & 1,125 & 1,200 & 1,425 & 1,750 \\
\hline Energy savings (kWh) & & 1,190 & 1,545 & 1,965 & 2,380 \\
\hline Electric price $(\$ B D / k W h)$ & & 0.18 & 0.18 & 0.18 & 0.18 \\
\hline Annual savings (\$BD) & & 420 & 546 & 693 & 840 \\
\hline \multicolumn{6}{|l|}{ Payback period (years) } \\
\hline - Without fiscal incentives & & 2.7 & 2.2 & 2.1 & 2.1 \\
\hline \multicolumn{6}{|l|}{ - With fiscal incentives: } \\
\hline Taxable income (US\$2011) & Tax rate & & & & \\
\hline$<12,000$ & $25 \%$ & 2.0 & 1.6 & 1.5 & 1.6 \\
\hline$>12,000$ & $40 \%$ & 1.6 & 1.3 & 1.2 & 1.2 \\
\hline
\end{tabular}

Source: Slightly modified from Perlack and Hinds (2003). 
centres (Rabinovitch and Leitman 2004). The most noteworthy example of an urban policy to counter these developments is the Sustainable Urban Development programme, first implemented in Curitiba in the 1960s. Curitiba, the capital of Paraná state, has 1.8 million inhabitants (the metropolitan region has 3.2 million inhabitants), which makes it the country's eighth largest urban centre in terms of population.

\section{The initiative}

The starting point of Sustainable Urban Development stems from the 1965 creation of the Institute for Research and Urban Planning of Curitiba, an independent public authority.The Institute conducted the drafting of the city's 1966 master plan, and in subsequent decades, it coordinated the development of a series of integrated policies to be executed by the municipal authorities (Rabinovitch 1992; Rabinovitch and Leitman 2004), including the following:

- Relocating employment to areas outside the city centre (e.g. through the creation of an 'industrial city' in a concentrated area west of Curitiba, where industries are bound by strict environmental regulations);

- Developing a system of roads with exclusive busways at their centre (Bus Rapid Transit system);

- Rationalizing of the integrated transport system;

- Improving land use legislation, providing clear incentives for commercial developments to be located as closely as possible to the public transport axes and outside the city centre;

- Developing green areas across the city, some of them in former slum areas; and

- Improving, either through relocation or not, of the quality of life in slum areas, from the point of view of public transport access, garbage collection and flood prevention.

Important factors for the success of Sustainable Urban Development in Curitiba included the continuity and consistency of the Institute for Research and Urban Planning's policies; the holistic vision of the institution (which allowed it to design policies accounting for the economic, social and environmental aspects of urban planning); the harmonization between urban development and the legal framework on construction and environment; the availability of specific funding for the project; the fact that the city had been able to easily purchase land for transport, residential and industrial use; and the hydrological features of the area that facilitated the creation of green areas across the city (de Oliveira 2001).

\section{Functioning}

The Institute for Research and Urban Planning coordinated various aspects of urban development and ensured continuity and consistency in planning processes amid turnover in city administrations. The Bus Rapid Transit system, which has 
a construction cost of US $\$ 3$ million per kilometre, pays for itself. A city agency manages the operation of the system, which is served by private companies. The law stipulates that transportation revenue is exclusively dedicated to paying the Bus Rapid Transit system (World Bank, 2010). All the infrastructure costs of the Bus Rapid Transit system have been financed by the municipality (which still pays for the maintenance of the roads), whereas private bus operators finance the buses and station maintenance themselves, without external funding. The InterAmerican Development Bank (IDB) provided more than $\$ 262$ million in loans to the municipality for additional expansion of the Bus Rapid Transit system (IDB 1995, 2004, 2011).

Policies for spatially reorganizing the city have been financed by a set of taxes and public funds. For example, special property taxes for new neighbourhoods close to green areas partially finance the construction of such green areas and improvements to living conditions in slums. Historical rights to develop certain areas may be exchanged for rights to develop other city areas deemed more propitious for further urban development. In addition, the municipality sells construction and forest exploitation rights, which partially finances slum improvement and historic building preservation. The Institute for Research and Urban Planning regulates and monitors the transfer of development rights among interested parties.

For waste collection, the city implemented the Green Exchange Programme, which compensates people for collecting garbage and litter and handing it in at neighbourhood centres. This programme allows the municipality to save money on waste collection and to create a cleaner living environment while providing additional livelihoods for the poor (World Bank 2010). In addition to these self-financing mechanisms, an Inter-American Development Bank grant of about $\$ 850,000$ (IDB 2009) and a grant from the Agence Française de Développement (AFD) of more than $\$ 50$ million (AFD 2011) have supported diverse urban development projects.

\section{Assessment of the initiatives}

\section{Major themes: enabling conditions and financing}

\section{Enabling conditions}

The enabling conditions for the four assessed initiatives have some elements in common. First, the initiatives share the political will and engagement of key local leaders. The Costa Rican Forestry Law that underpins the PES scheme was the result of dedication and particular support from the then Minister for the Environment, who is also the author of a scientific assessment of the feasibility of the scheme. FONAG was supported by the then mayor of Quito, who was interested in fundraising for watershed protection (Pérez et al. 2006). The then prime minister of Barbados personally advocated for the initial fiscal incentives to help stimulate the 
market for solar water heaters, pointing at their performance and potential energy savings (Perlack and Hinds 2003). In Curitiba, the city's mayor from 1971 to 1992 had previously been president of the Institute of Research and Urban Planning, and drafted the city's 1966 master plan, laying the foundation for today's Sustainable Urban Development initiative (World Bank 2010).

Second, the implementation or modification of the regulatory framework for environment and economy catalysed the conception of the four initiatives. While the local initiatives were only driven by internal issues (e.g. population growth in Curitiba and concerns around water availability and quality in Quito), the national initiatives (FONAFIFO in Costa Rica and solar water heaters in Barbados) were also influenced by international factors. The suppression of forestry subsidies in Costa Rica during the mid-1990s, imposed by the Structural Adjustment Programmes of the World Bank, fostered the pursuit of another way to support forest protection. In Barbados, the first oil peak in 1973-1974 forced the government to find substitutes for imported oil, turning it towards solar energy.

\section{Financing}

Table 13.6 highlights the funding sources and the main financing mechanisms employed to finance the four initiatives at their different stages. Following are the important lessons.

Public pre-investment finance was employed to scale up the level of investments in all four cases (UNEP 2011). During the capacity-building and initiation phases, public funds and donors prevailed as the main source of funding for research and development and for creating institutional capacity.

During the initiative's operational phase, the source of funds was diverse and public funding still played a key role.Very well-defined public-private mechanisms were established to support PES in Costa Rica, protect watersheds in Quito, to develop public transport in Curitiba and to boost the national solar water heater industry in Barbados. The private sector is fully engaged in the Barbados and Curitiba initiatives, in which it reacted positively to the financial incentives provided by public funding. Fiscal policies are in place to support PES in Costa Rica and to drive Sustainable Urban Development in Curitiba. In Barbados, the solar water heater initiative is fully funded and driven by fiscal policies.

Multilateral development finance institutions (e.g. IDB and the World Bank), and bilateral development finance institutions (e.g. the French Development Agency, Dutch Entrepreneurial Development Bank FMO, the German Development Fund and USAID) have played a key role in supporting all these initiatives (with the exception of solar water heaters in Barbados). In Curitiba, IDB provided several loans and grants to the local government for developing the transport system and implementing sustainable urban policies. The World Bank is involved in forest protection in Costa Rica through the provision of loans and grants. Bilateral development finance institutions have provided financial assistance through grants. 
TABLE 13.6 Type of Funding by Initiative and Phase

\begin{tabular}{|c|c|c|c|c|}
\hline \multirow[t]{2}{*}{ Initiatives } & \multicolumn{3}{|l|}{ Initiative-specific funding } & \multirow{2}{*}{$\begin{array}{l}\text { General funding: allocations } \\
\text { from other sources }\end{array}$} \\
\hline & $\begin{array}{l}\text { Capacity building: research and } \\
\text { development, institutional capacity }\end{array}$ & $\begin{array}{l}\text { Initiation: capital } \\
\text { expenditures, set-up costs }\end{array}$ & Maintenance: funding for operating costs & \\
\hline $\begin{array}{l}\text { National Forestry } \\
\text { Financing Fund, } \\
\text { Costa Rica }\end{array}$ & $\begin{array}{l}\text { FONAFIFO was established } \\
\text { by public funds to set up } \\
\text { PES for forest management. }\end{array}$ & $\begin{array}{l}\text { A fiscal policy was started } \\
\text { to nourish the fund } \\
\text { ( } 3.5 \% \text { of the fuel tax). }\end{array}$ & $\begin{array}{l}\text { Through a PES scheme nourished } \\
\text { by contributions from public } \\
\text { funds ( } 3.5 \% \text { of the fuel tax), } \\
\text { public-private partnerships and } \\
\text { Certificates of Environmental } \\
\text { Services (buyers of these } \\
\text { certificates receive an equivalent } \\
\text { deduction in their income tax) }\end{array}$ & $\begin{array}{l}\text { Grants from the World } \\
\text { Bank and the German } \\
\text { Development Fund } \\
\text { Loan from the World Bank }\end{array}$ \\
\hline $\begin{array}{l}\text { Water Protection } \\
\text { Fund, Quito, } \\
\text { Ecuador }\end{array}$ & $\begin{array}{l}\text { A study supported by } \\
\text { a USAID grant } \\
\text { recommended the creation } \\
\text { of a water protection } \\
\text { scheme based on local } \\
\text { funding. }\end{array}$ & $\begin{array}{l}\text { Seed capital provided by } \\
\text { public enterprises and } \\
\text { donors }\end{array}$ & $\begin{array}{l}\text { Semi-PES scheme } \\
\text { Public enterprises and minor } \\
\text { contributions from institutional } \\
\text { and private donors }\end{array}$ & $\begin{array}{l}\text { Grants from USAID, } \\
\text { the German } \\
\text { Development Fund, } \\
\text { Dutch Entrepreneurial } \\
\text { Development Bank, } \\
\text { Inter-American } \\
\text { Development Bank } \\
\text { and in-kind payment } \\
\text { from the Environmental } \\
\text { Systems Research } \\
\text { Institute }\end{array}$ \\
\hline
\end{tabular}


Solar Water Heater initiative in

Barbados

Sustainable Urban

Development in

Curitiba, Brazil
A public grant to the private sector helped spur the development of a marketable solar water heater.

Public funds founded the Institute for Research and Urban Planning of Curitiba and designed the city's sustainable development plan.

A loan from a public bank helped the private sector to carry out the first project.

Public and private funds

Fiscal policies (i.e. tax reductions) aim to encourage the use of solar water heaters.

Three private companies dominate the Barbadian solar water heater market.

Public-private partnerships for the Bus Rapid Transit system and for the industrial city of Curitiba

Fiscal policies to finance slum relocation, park construction and heritage preservation

Inter-American Development Bank loans to government of Curitiba for improving public transport
Minor solar water heater donations to households

by the government

\section{Inter-American}

Development Bank grant for urban development French Development Agency grant for transport and biodiversity conservation 


\section{Green economy performance}

When applying the grading system developed in Section 2 to the four environmental initiatives with the aim of assessing their green economy performance, we obtain the following findings (see Table 13.7).

\section{National forestry financing fund, Costa Rica}

The PES system to protect forests in Costa Rica shows good performance for the three pillars of sustainable development and can therefore be considered a green economy success story. The PES scheme in Costa Rica contributes to forest expansion, includes special provisions to enhance social inclusiveness, has boosted the forest industry and has fostered private investments to the sector. Sub-national studies show that the PES scheme has lowered deforestation rates and contributed to forest expansion (Daniels et al. 2010). From 2000 to 2010, net forest cover increased by approximately 23,000 hectares per year (FAO 2010). In the initial stage of the initiative, social aspects were not sufficiently taken into account, but some recent measures have enhanced minority access to the programme, including abolishing the requirement of land ownership, introducing PES for agroforestry services and prioritizing cantons with a low social development index (Madrigal et al. 2006). Furthermore, reforestation activities are at least 33\% of permanent employment in the forestry sector (Arias 2004).

Forest plantations have become the largest permanent cultivation in the country, contributing more than $\$ 141$ million to the gross domestic product in 2001 . The forest industry has experienced significant growth since the 1997 implementation of PES, reaching an installed capacity of 446 cubic metres of timber per year in 2001. The PES has also fostered private investments in the forestry sector. For example, from 1997 to 2002, private investments were four times the investment made by FONAFIFO (Arias 2004). The initiative shows that a significant growth of the forestry industry can not only be achieved with forest depletion but can also go hand in hand with sustainable forest management and expansion of forest covers, creating a long-term source of revenue.

\section{Water protection fund, Quito, Ecuador}

This initiative obtains low evaluations for the three dimensions. In terms of real impact on ecosystem protection, improved watershed management has only been implemented in 65,000 of the potential 520,000 hectares (UNEP 2010). Furthermore, there is no reliable evidence about positive environmental changes that the set of all upstream projects financed by FONAG have produced on the availability and quality of water in Quito. Only a few projects produced observable positive local impacts (Pérez et al. 2006). Concerning social inclusiveness, despite the fact that more than 1,800 farmers upstream are estimated to receive indirect economic benefits (UNEP 2010), there are no specific provisions to ensure social 
TABLE 13.7 Green Performance of the Initiatives

\begin{tabular}{|c|c|c|c|}
\hline \multirow[t]{2}{*}{ Initiatives } & \multicolumn{3}{|c|}{ Green performance based on evidence } \\
\hline & Ecosystem protection & Social equity & Economic growth \\
\hline $\begin{array}{l}\text { National Forestry } \\
\text { Financing } \\
\text { Fund, Costa } \\
\text { Rica }\end{array}$ & $\begin{array}{l}\text { Good: PES scheme has } \\
\text { lowered deforestation } \\
\text { rates and contributed } \\
\text { to forest expansion. }\end{array}$ & $\begin{array}{l}\text { Good: Although } \\
\text { social aspects were } \\
\text { not sufficiently } \\
\text { taken into account } \\
\text { during the initial } \\
\text { stages, some recent } \\
\text { measures have } \\
\text { readdressed this } \\
\text { issue. }\end{array}$ & $\begin{array}{l}\text { Good: Forest } \\
\text { plantations } \\
\text { and the forest } \\
\text { industry have } \\
\text { experienced } \\
\text { a significant } \\
\text { growth and } \\
\text { contributed } \\
\text { significantly } \\
\text { to the gross } \\
\text { domestic } \\
\text { product. } \\
\text { The PES has } \\
\text { fostered private } \\
\text { investments } \\
\text { in the forestry } \\
\text { sector. }\end{array}$ \\
\hline Water Protection & Poor: & Poor: & Poor: \\
\hline $\begin{array}{l}\text { Fund, Quito, } \\
\text { Ecuador }\end{array}$ & $\begin{array}{l}\text { There is no reliable } \\
\text { evidence } \\
\text { about positive } \\
\text { environmental } \\
\text { changes that the set of } \\
\text { all upstream projects } \\
\text { have produced on the } \\
\text { availability and quality } \\
\text { of water in Quito. }\end{array}$ & $\begin{array}{c}\text { There are no specific } \\
\text { provisions to ensure } \\
\text { social inclusiveness. }\end{array}$ & $\begin{array}{l}\text { There is no reliable } \\
\text { evidence that } \\
\text { the initiative is } \\
\text { contributing to } \\
\text { the economic } \\
\text { growth of the } \\
\text { areas where it is } \\
\text { operating. }\end{array}$ \\
\hline $\begin{array}{c}\text { Solar water } \\
\text { heaters in } \\
\text { Barbados }\end{array}$ & $\begin{array}{l}\text { Good: This initiative } \\
\text { provides global and } \\
\text { local environmental } \\
\text { benefits. }\end{array}$ & $\begin{array}{l}\text { Medium: Fiscal } \\
\text { exceptions have } \\
\text { yielded positive } \\
\text { results among } \\
\text { middle-income } \\
\text { households. } \\
\text { However, tax } \\
\text { incentives do not } \\
\text { guarantee the } \\
\text { inclusion of the } \\
\text { poorest households. }\end{array}$ & $\begin{array}{l}\text { Good: The } \\
\text { programme has } \\
\text { had a positive } \\
\text { spill-over effect } \\
\text { on the overall } \\
\text { economy. }\end{array}$ \\
\hline $\begin{array}{l}\text { Sustainable } \\
\text { Urban } \\
\text { Development } \\
\text { in Curitiba, } \\
\text { Brazil }\end{array}$ & $\begin{array}{l}\text { Good: This initiative } \\
\text { has had very positive } \\
\text { impacts on the } \\
\text { environment and } \\
\text { society. }\end{array}$ & $\begin{array}{l}\text { Good: This initiative } \\
\text { has effectively } \\
\text { addressed social } \\
\text { inclusiveness. }\end{array}$ & $\begin{array}{c}\text { Good: Sustainable } \\
\text { development } \\
\text { policies have } \\
\text { fostered } \\
\text { economic } \\
\text { development. }\end{array}$ \\
\hline
\end{tabular}


inclusiveness. Furthermore, as decisions in FONAG are made by constituents based on their financial contribution, there is a risk of social exclusion (Pérez et al. 2006).

It is not clear whether this initiative is contributing to the project area's economic development. Though some projects are creating the right conditions for developing ecotourism and forestry sector activities, there is no reliable evidence that the initiative is contributing to the economic growth of the areas where it is operating. Since a sound evaluation of the eventual economic, social and environmental benefits of the initiative is absent, the initiative cannot yet be considered a green economy success story, nor can it serve as an example for replication in other areas. A possible explanation might lie in the amount of funding that was made available, which is quite modest, considering the forest area it needs to protect in order to ensure the qualitative and sufficient water supply to the city of Quito. FONAG is the only initiative among the four that is not state-controlled.

\section{Solar water heaters in Barbados}

The solar water heater initiative in Barbados obtains good evaluations for environmental sustainability and economic development, and a medium grade in social equity. It provides global and local environmental benefits due to the reduction of fossils fuels. The use of solar water heaters contributes to the reduction of climate change and local air pollution by reducing the consumption of fossil fuels (and consequently greenhouse gas emissions and air pollutants). For example, in 2002 carbon savings amounted to 15,000 metric tons, which represented $4 \%$ of the emissions from all Barbadian carbon sources. Fiscal exceptions have yielded positive results among middle-income households. However, tax incentives might not be the most appropriate instrument to achieve the inclusion of the poorest households, which do not have sufficient income to qualify for a tax deduction (Perlack and Hinds 2003).

The programme has had positive spill-over effects on the overall economy. It has fostered the creation and further development of the solar water heater industry in Barbados, which has become the most consolidated in the Caribbean. Sixty percent of the heaters are produced locally (Government of Barbados and IDB 2010). The country has the developing world's highest per capita rate of solar water heater installations. In 2009, 324 heaters were in operation per 1,000 inhabitants (Weiss and Mauthner 2011). Economic benefits have been larger that the tax costs. The cumulative tax cost of solar water heater incentives is estimated at about $\$ 10.8$ million through 2002, whereas the cumulative value for energy savings is in the order of $\$ 134$ million (Perlack and Hinds 2003). Furthermore, Barbados benefits from the initiative, as its reduced dependence on fossil fuel imports renders the country less vulnerable to the effects of shocks in the international oil price.

\section{Sustainable urban development in Curitiba, Brazil}

The Sustainable Urban Development initiative resulted in very positive impacts on environment and society, enhanced social inclusiveness and fostered economic development in the city. 
The initiative has achieved several environmental benefits, including an increase in the green area per person from 1 square metres in 1970 to 50 square metres in 2008. Of all trips in the city, $45 \%$ are made in public transport; $32 \%$, on foot or bike using the city's 120-kilometre network of bike lanes. Moreover, the city has low levels of unregulated waste dumping. Around 13\% of waste is recycled. Proper tire collection has reduced dengue disease by $99.7 \%$. Furthermore, relocating and improving slum areas and replacing them with green spaces have led to more effective water regulation. Curitiba has one of the lowest rates of ambient air pollution in Brazil due to the strengthening of public transport, the creation of green areas and the good environmental regulation of the industrial city. Greenhouse gas emissions in the area have dropped (World Bank 2010).

Sustainable Urban Development in Curitiba has had a favourable impact on social inclusiveness. It has achieved a positive effect on job creation (estimated at 200,000 jobs). The garbage collection programme has created alternative sources of income for the poorest. Income from the sale of recyclables is being used to support social programmes. Slum areas have decreased and areas for unofficial occupancy have been designed and included in the city planning. The decentralization of city services to areas that are easily reached by public transport has significantly increased the social inclusiveness of the services provided. The flat 'social fare' for public transport has benefitted around $80 \%$ of the population, especially the poorest as they tend to commute over longer distances. In addition, the city has provided compensation when relocating slums and promoted the diversity of income groups in new neighbourhoods (World Bank 2010).

Sustainable development policies have fostered economic development. The reorganization of the city and the creation of an industrial city have boosted economic growth. Curitiba's Industrial City produces $20 \%$ of Paraná's exports and it accounts for $25 \%$ of the state's value added tax revenue on sales and services. After three decades, the industrial city hosts more than 7,000 companies, including the car manufacturer that produces Bus Rapid Transit system buses. By improving infrastructure and traffic plans, the city has saved on construction costs. The Bus Rapid Transit system pays for itself without government subsidies. It has also helped to diminish economic losses that result from traffic congestion. The cost of building parks and relocating slums has been estimated at five times less than the projected cost of building concrete canals to control the significant flood risk. Preservation of culture and heritage maintains a lively cityscape and attracts tourism (World Bank 2010).

\section{Lessons learned and opportunities for improvement}

\section{Strengths}

The analysis of these initiatives helps to draw some lessons learned and identify their potential for improvement. When determining the main strengths, weaknesses, challenges and opportunities of the initiatives, we arrive at the conclusions that can be found in Table 13.8 . 
TABLE 13.8 Strengths, Weaknesses, Challenges, Opportunities Matrix

\begin{tabular}{|c|c|c|c|c|}
\hline Initiatives & Strengths & Weaknesses & Challenges & Opportunities \\
\hline $\begin{array}{l}\text { National Forestry } \\
\text { Financing Fund, } \\
\text { Costa Rica }\end{array}$ & $\begin{array}{l}\text { - Flexibility on adapting } \\
\text { regulations over time for } \\
\text { obtaining funding sources } \\
\text { - } \begin{array}{l}\text { Effective compliance and } \\
\text { monitoring mechanisms }\end{array}\end{array}$ & $\begin{array}{l}\text { There are not enough } \\
\text { incentives for attracting the } \\
\text { participation of some kinds } \\
\text { of landholders and some } \\
\text { modalities }\end{array}$ & $\begin{array}{l}\text { - Available funding } \\
\text { covers only a } \\
\text { percentage of the } \\
\text { requests }\end{array}$ & $\begin{array}{l}\text { To look for new sources } \\
\text { of international funding } \\
\text { mechanisms (e.g. } \\
\text { REDD+) }\end{array}$ \\
\hline $\begin{array}{l}\text { Water Protection Fund, } \\
\text { Quito, Ecuador }\end{array}$ & $\begin{array}{l}\text { - Political and financial } \\
\text { stability }\end{array}$ & $\begin{array}{l}\text { - There are incentives for } \\
\text { free-riding } \\
\text { - The water price does not } \\
\text { reflect watershed protection } \\
\text { costs } \\
\text { - Scientific basis for benefits is } \\
\text { weak } \\
\text { - Low monitoring and } \\
\text { compliance for watershed } \\
\text { protection }\end{array}$ & $\begin{array}{l}\text { - Current funding } \\
\text { is insufficient } \\
\text { to improve } \\
\text { watershed } \\
\text { protection } \\
\text { activities }\end{array}$ & $\begin{array}{l}\text { - To transit into a well- } \\
\text { defined PES scheme }\end{array}$ \\
\hline $\begin{array}{l}\text { Solar water heaters in } \\
\text { Barbados }\end{array}$ & $\begin{array}{l}\text { - Appropriate mix of fiscal and } \\
\text { trade incentives }\end{array}$ & $\begin{array}{l}\text { Fiscal incentives attract } \\
\text { mainly middle-income } \\
\text { households }\end{array}$ & $\begin{array}{l}\text { High up-front } \\
\text { costs of solar } \\
\text { water heaters }\end{array}$ & $\begin{array}{l}\text { To extend to other } \\
\text { Barbadian sectors and } \\
\text { Caribbean countries }\end{array}$ \\
\hline $\begin{array}{l}\text { Sustainable Urban } \\
\text { Development in } \\
\text { Curitiba, Brazil }\end{array}$ & $\begin{array}{l}\text { Well-interconnected social, } \\
\text { economic and environmental } \\
\text { policies } \\
\text { - Leadership and continuity } \\
\text { - Institutionalized planning }\end{array}$ & - Lack of regional integration & $\begin{array}{l}\text { - Population } \\
\text { growth, also due } \\
\text { to immigration } \\
\text { - Changing } \\
\text { consumption } \\
\text { patterns }\end{array}$ & $\begin{array}{l}\text { To launch an initiative } \\
\text { beyond the borders of } \\
\text { Curitiba that integrates } \\
\text { the social, environmental } \\
\text { and economic aspects }\end{array}$ \\
\hline
\end{tabular}


The strengths of the policies are as diverse as the policies themselves. The high flexibility in obtaining funding, the capacity to adapt over time and the strong compliance mechanisms are strengths of the PES scheme in Costa Rica. The PES scheme is supported by several complementary regulations, some of which can be adapted over time. This initiative includes randomized monitoring visits to farms, undertaken by both independent evaluators and external audits. It also allows for flexibility for obtaining funding sources (Madrigal et al. 2006).

FONAG, in Ecuador, shows both political and financial stability in its operations. The initiative is a local solution, financed by private resources and without direct intervention by the government (Pérez et al. 2006).

In the Barbados initiative, the appropriate mix of fiscal measures and custom incentives for encouraging solar water heater use is the strong point. These have allowed the development of a national solar hot water industry and promoted the introduction of solar water heaters by households.

Sustainable Urban Development's success is based on the implementation of a coherent approach, the leadership of local authorities and the institutionalization of urban planning. It is based on well-interconnected social, economic and environmental policies. There has been significant and consistent political commitment to sustainable urban planning. The Institute for Research and Urban Planning of Curitiba as a public institution of the municipality has provided integrated, crosssector urban planning and monitoring for several decades (World Bank 2010).

\section{Weaknesses}

All policies present weaknesses that will affect long-term sustainability if unaddressed. In the Costa Rican initiative, transaction costs for landholders are still high $(15 \%)$ and landholders who face high opportunity costs resulting from forest preservation do not have sufficient incentives to participate. Some PES modalities, such as reforestation projects, have been disadvantaged because of specific requirements. For example, landholders who apply for reforestation projects are required to pause their agricultural activities until assessment and procurement processes have ended, which can entail economic losses. Incentives to attract landholders, who face high opportunity costs, have been insufficient (Madrigal et al. 2006).

FONAG has to resolve free-riding problems, internalize watershed protection costs, improve the scientific basis of the scheme and strengthen monitoring and compliance. Concerning free-riding, as financial contributions to the fund are voluntary, there are incentives for small beneficiaries to not contribute to the payment for services provided. Further, the current water fees do not include the full cost of services provided, which include watershed protection. The mechanism's implementation was not based on scientific data about the hydrology of the area. With regard to monitoring and compliance, there is no reliable monitoring of the impacts of sustainable management activities on the improvement of water flows nor are there any penalties for lack of compliance (Pérez et al. 2006). 
The solar water heater initiative in Barbados should find ways to include both the higher and lower-income households in the programme because, despite the high rate of solar water heater penetration, fiscal measures do not sufficiently encourage the introduction of solar water heaters in the lower-income households. Further, the measures do sufficiently incentivize higher income households that prefer electric water heaters over rooftop solar panels for aesthetic reasons (Perlack and Hinds 2003).

The achievements of Curitiba's initiative are at stake if a better regional integration is not reached. Integration in the rest of the state could be improved. Polluting industries are being authorized to settle in surrounding municipalities, and Curitiba's water supply depends on reservoirs controlled by other municipalities (Lubow 2007). Additionally, as a result of migration and a lack of innovation of the BRT system since its introduction, Curitiba's achievements are partially offset (e.g. car ownership has risen and use of public transport has decreased). Currently, the policy is by-passed by other cities inspired by Curitiba's example (Giacomini Martínez et al., 2016).

\section{Challenges}

A lack of funding presents the main challenge to three of the initiatives. In Costa Rica, funding is available only for $40 \%$ of the participation requests that comply with the PES eligibility requirements (Madrigal et al. 2006). FONAG finances only $13 \%$ of the 520,000 upstream hectares of watersheds. Financial resources obtained to date are insufficient to include the whole area of the two ecological reserves in sustainable management activities (Pérez et al. 2006). In Barbados, where the funding for the initiative originates from final consumers directly, the lack of financing facilities to overcome the high upfront costs is an economic barrier for the lowerincome households to the point that monthly repayment rates equal the installed and electric costs for electric water heaters (Schwerin 2010).

The main challenges to Urban Sustainable Development in Curitiba are shifting consumption patterns and population growth. Successful economic growth has led to increased car ownership. A measure to counter this might be to continuously upgrade the public transport system in order to remain an appealing alternative to private vehicles (Lubow 2007). Migration has become a major challenge for sustaining this policy over time. The city's population has tripled between 1970 and 2008 (World Bank 2011), and although the number of people living in slums is much lower in Curitiba than in other Brazilian cities, slum inhabitants still compose $8 \%$ of the city's population (Grostein 2001).

\section{Opportunities}

Finally, opportunities for improvement and learning are manifold. For example, in order to increase availability of funding, FONAFIFO needs to be able to integrate new international financial mechanisms that compensate forest protection. An 
example could be the Reducing Emissions from Deforestation and Degradation (REDD) scheme under the United Nations Framework Convention on Climate Change. FONAFIFO is currently involved in the REDD readiness phase financed by the World Bank/Forest Carbon Partnership Facility. The REDD readiness package also includes the development of a national forest baseline, the creation of a national measurement, reporting and verification system and the development of an environmental and social management framework that includes consultation processes involving all relevant stakeholders (World Bank 2009). These elements could significantly strengthen the PES scheme.

FONAG has the potential to evolve towards a well-defined PES scheme for watershed protection that guarantees water provision to the city of Quito. Once consolidated as a PES scheme, it could be able to take the advantages of a REDD+ mechanism to obtain better access to international funding. However, in order to become a PES scheme, the initiative needs to adopt adequate supportive legislation and regulation, strengthen tenure security in the basins, enhance the scientific basis of the activities with regard to the local hydrology (specifically concerning the link between watershed protection and water supply), include provisions to address leakage issues and provide guarantees that water supply and treatment will remain affordable for the poorest inhabitants of Quito (Pérez et al. 2006).

Barbados faces the same kind of challenges as other Caribbean nations with respect to high fuel costs. For this reason, the Barbados solar water heater initiative has a high potential for replication in the region. The potential solar water heater market in the Caribbean is estimated at 798,000 solar water heater units (based on an envisaged penetration rate of between 10 to $50 \%$, depending on the country (Solar Dynamics 2010). Barbadian solar water heater manufacturers are already creating the conditions that will allow them to meet this market demand. Strengthening current regional frameworks for renewable energy could help to create the enabling environment. This could be achieved, for example, through the Caribbean Renewable Energy Development Programme launched in 1998 by the Caribbean Community and UNDP (Schwerin 2010). Furthermore, solar water heater use could be extended beyond the domestic use, which would scale up the use of solar energy in Barbados.

Similarly, the Sustainable Urban Development initiative in Curitiba could be extended to other cities. The launch of an ambitious initiative beyond the borders of Curitiba that integrates the social, environmental and economic aspects will enable a lasting progress and will prevent development disparities within the region.

Since 2014, all four initiatives have growth, matured and served as a model for other countries. For instance, the Payments for Environmental Services pioneered by Costa Rica has become particularly common in Latin America, embraced by countries like Mexico, Colombia and Chile. More than 20 water protection funds have seen the light in Latin America countries. They are organized under the 'The Latin American Alliance of Water Funds'. ${ }^{5}$ The solar water heater experience of Barbados has been expanded to the other Caribbean countries which are providing incentives to promote renewable energy such as Jamaica in building its own wind 
development and Dominica have all sought to develop geothermal energy projects (The Guardian, 2015). Sustainable Urban Development continues in Curitiba where a new Land Zoning, Use and Occupation Law was adopted late 2019 which will guide the future development of the city for the next 10 years with the support of several public-private programmes. ${ }^{6}$

\section{Conclusion}

The main objective of this research is to measure the environmental, social and economic performance of environmental initiatives that have been touted as green economy success stories by diverse international organizations, including UNEP. The chapter assessed in detail four policies that are currently being implemented in Latin America and the Caribbean, covering four sectors (forests, freshwater, renewable technologies and cities). We propose a methodological framework that includes evidence-based criteria and a grading system built on existing indicators. In addition, the study analyses the enabling conditions that favoured the development of the initiatives, the ways in which they are operated and financed and the main challenges and opportunities for further improvement and strengthening. The application of our method to the four case studies revealed the following conclusions.

First, despite the fact that the environmental initiatives assessed are catalysing the transition from a business as usual development pathway to one that is more resource efficient and socially inclusive, not all fulfil the criteria of green economy policies. The PES scheme for forest protection in Costa Rica and the Sustainable Urban Development initiative in Curitiba, Brazil can clearly be considered 'green economy success stories', as they show good performance for the three pillars of sustainable development. These initiatives are closely followed by the solar water heater initiative in Barbados, which obtains good economic and environmental performance. However, the initiative receives a medium grade on social equity, as the programme does not yet guarantee full social inclusion (particularly as it excludes lower-income households from its potential benefits). FONAG, in Ecuador, is far from reaching the criteria of a green economy policy because there is no reliable evidence regarding the positive impact of upstream watershed management on the availability and quality of Quito's water resources. The way that the fund operates does not guarantee that programmes and projects will enhance social inclusion, and it is not clear that this initiative is contributing to the protected area's economic development.

Second, despite the fact that the enabling conditions that promoted the initiatives differed, some key elements for policy-making can be identified: the establishment of sound regulatory frameworks, the full engagement of local leaders and the success of employing public funds to leverage private investments for addressing environmental issues.

Third, the analysis of the strengths, weaknesses, challenges and opportunities of these environmental initiatives shows that the strengths of the policies are as diverse 
as the policies themselves (e.g. flexibility on both obtaining funding and adapting over time in FONAFIFO, political and finance stability in FONAG, the appropriate mix of fiscal measures in Barbados and the implementation of a coherent approach in Curitiba). All policies present weaknesses that must be addressed in order to improve their effectiveness and likelihood of long-term sustainability (e.g. transaction costs are still high for landholders in the PES scheme in Costa Rica, free-riding problems in FONAG, economic barriers for customers in Barbados and population growth in Curitiba). The main challenge faced by the policies is a lack of funding.

Fourth, despite the progress made since the first edition of this chapter (2014) in the development of measurements frameworks for assessing green economy progress and performance, the approach presented in this chapter remains valid for assessing specific green economy initiatives, in spite of their geographical diversity. Alternative methodologies developed so far have a national or sub-national scope, preventing the evaluation of the impacts of single initiatives and policies. Furthermore, the evidence-based criteria and a grading system are relevant to assess how the green economy initiatives are contributing to the SDGs.

Finally, we recognize that this research has two main caveats. First, for the assessment of the initiatives, we have relied on the accuracy of previous studies, studies that were not all peer-reviewed papers. Furthermore, the sample of policies may not be enough to draw general conclusions. In order to overcome these drawbacks, we recommend enlarging the number of initiative assessments and following a participatory approach with key stakeholders involved in their development and operation.

\section{Notes}

1 Some of these methodologies have been adapted to a sub-national level such as the Green Economy Progress Index, which has been used to measure Green Industry Progress in 18 Chinese Provinces (PAGE, 2019).

2 We based our choice on the set of indicators to assess environmental sustainability both in natural capital and in economic sectors proposed by the OECD (2011), which is presently the most complete and practical.

3 An important impact variable that is missing from this listing is governance. However, to the extent that good governance is required to achieve many impacts related to social equity, we assume that presence of good governance is necessary and implicit in the indicators we have laid out. Most indicators are criticized because they ignore enabling conditions and changes in the baseline contextual conditions.

4 FONAFIFO was established under the Payments for Environmental Services programme, by Forestry Law 7575 of 1997.

5 More information about 'The Latin American Alliance of Water Funds' is available at https://www.fondosdeagua.org/es/que-es-la-alianza/, last accessed 20 January 2020.

6 Additional information about recent development of Curitiba's urban planning is available at https://www.curitiba.pr.gov.br/noticias/prefeito-sanciona-a-nova-lei-de-zoneamento-uso-e-ocupacao-do-solo-de-curitiba/53099, last accessed 20 January 2020. 


\section{References}

Acosta, L.A., P. Maharjan, H. Peyriere, L. Galotto, R.J. Mamiit, C. Ho, B.H. Flores, and O. Anastasia., Green growth index: Concepts, methods and applications, GGGI technical report No. 5, Green Growth Performance Measurement (GGPM) Program, Global Green Growth Institute, Seoul. In: B.H. Flores, A. Sharma, A. Jacob et al., Green Growth Index: Concept, Methods and Applications, 2019, available at http://greengrowthindex.gggi.org/ wp-content/uploads/2019/12/Green-Growth-Index-Technical-Report_s1213.pdf, accessed January 202020.

Agence Française de Développement (AFD), 2011, Supporting sustainable urban mobility in Curitiba, available at www.afd.fr/en/carte-des-projets/supporting-sustainable-urbanmobility-curitiba, accessed May 2013.

Arias, G., Análisis del Impacto Económico y Social de las Plantaciones. Forestales en Costa Rica, Fundación para el Desarrollo de la. Cordillera Volcánica Central (FUNDECOR), San José, Costa Rica, 2004

Cisneros, J. and P. Loret, El fondo para la protección del agua. mecanismo financiero para la conservación y el cudado del agua en Quito, seminario internacional 'cogestión de cuencas hidrográficas experiencias y desafios', 2008, available at http://orton.catie.ac.cr/ repdoc/A2983e/A2983e11.pdf, accessed May 32013.

Daniels, A.E., K. Bagstad, V. Esposito, A. Moulaert and C.M. Rodriguez, 'Understanding the impacts of Costa Rica's PES: Are we asking the right questions?', Ecological Economics, 69: 2116-2126, 2010.

de Oliveira, M., "A trajetório do discurso ambiental em Curitiba (1960-2000)", Revista de Sociologia Política, 16: 97-106, 2001.

Echavarria, M. and P. Arroyo, 'Financing Watershed Conservation: The FONAG Water Fund in Quito, Ecuador', Quito, The Nature Conservancy, 2002.

Food and Agriculture Organization (FAO), 2010, 'Global Forest Resources Assessment 2010', available at http://www.fao.org/3/i1757e/i1757e00.htm, accessed December 172020.

Food and Agriculture Organization (FAO), 2011, 'The Republic of Costa Rica: General Information', available at http://www.fao.org/countryprofiles/index/en/?iso3=CRI, accessed August 202013.

Fund for Water Protection (FONAG), 2012, available at http://www.fonag.org.ec/inicio/ english-version.html, accessed August 202013.

Giacomini Martínez, J., I. Boas, J. Lenhart and A.P.J. Mol, Revealing Curitiba's flawed sustainability: How discourse can prevent institutional change. Habitat International, 53, 2016.

Government of Barbados and Inter-American Development Bank (IDB), 'Sustainable Energy Framework for Barbados', Barbados 2010.

Grostein, M.D., "Metrópole e Expansão Urbana: A Persistência de Processos 'Insustentáveis" São Paulo em Perspetivam 15 (1): 13, 2001.

Headley O., 'Barbados Renewable Energy Scenario: Current Status and rojections to 2010', Centre for Research Management and Environmental Studies, Faculty Science and Technology, Barbados, 2001, available at http://www.terryally.com/library/oheadleyrenewable.html, accessed August 202013.

Inter-American Development Bank (IDB), 'BR0209: Urban Transport Curitiba', 1995, available at http://www.iadb.org/en/projects/project,1303.html?id=BR0209, accessed May 52013.

Inter-American Development Bank (IDB), 'BR0375 : Urban Transportation Curitiba II', Washington DC, 2004, available at http://www.iadb.org/en/projects/project,1303. html?id BR0375, accessed May 102013. 
Inter-American Development Bank (IDB), 'Bienes y servicios ambientales: mercados no tradicionales, mecanismos de financiamiento y buenas prácticas en América Latina y el Caribe', Washington DC, 2006, available at https://publications.iadb.org/es/publicacion/15361/bienes-yservicios-ambientales-mercados-no-tradicionales-mecanismos-de, accessed December 17 2020.

Inter-American Development Bank (IDB), 'BR-L1083: PROCIDADES-Curitiba: Curitiba Integrated Social and Urban Development', Washington DC, 2009, available at http://www. iadb.org/en/projects/project,1303.html?id BR-L1083, accessed May 52013.

Inter-American Development Bank (IDB), 'BR-T1165: Support to Improve City Logistics Performance in Curitiba', Washington, DC, 2011, available at http://www.iadb.org/en/ projects/project,1303.html?id BR-T1165, accessed May 102013.

International Institute for Environment and Development (IIED), Watershed markets, Case studies: Costa Rica - national payment for environmental services (PES) programme, available at http://www.watershedmarkets.org/casestudies/Costa_Rica_National_PES_eng.html, accessed August 202013.

Lubow, A., 'Recycle city: The road to Curitiba', New York Times, 20 May 2007, available at http://www.nytimes.com/2007/05/20/magazine/20Curitiba-t.html?pagewanted all, accessed August 202013.

Madrigal R., and F. Alpízar, 'Fondo Nacional del Agua, Ecuador'. In: F. Alpízar, C.J. Pérez, M. Niklitschek, M. Otárola, and R. Madrigal, eds., Buenas Prácticas en la Aplicación de Mecanismos de Financiamiento para la obtención de Servicios Ambientales de Prácticas Forestales y Agrícolas Sostenibles en América Latina y El Caribe, Red de Medio Ambiente, Chapter 4, 1-12, IDB, 2006.

Madrigal, R., F. Alpízar and M. Otárola, 'Fondo Nacional de Financiamiento Forestal, Costa Rica’. In: F. Alpízar, C.J. Pérez, M. Niklitschek, M. Otárola, and R. Madrigal, eds., Buenas Prácticas en la Aplicación de Mecanismos de Financiamiento para la obtención de Servicios Ambientales de Prácticas Forestales y Agrícolas Sostenibles en América Latina y El Caribe, Red de Medio Ambiente, Chapter 5 1-18, LOCATION, IDB, National Fund for Forest Financing (FONAFIFO), 2006, available at http://www.fonafifo.go.cr/paginas_espanol/ proyectos/e_pr_reforesta.htm, accessed August 202013.

Organisation for Economic Co-operation and Development (OECD), 'Towards Green Growth: Monitoring Progress OECD Indicators', Paris, 2011, available at http://www.oecd. org/dataoecd/37/33/48224574.pdf, accessed May 152013.

PAGE, 'The Green Economy Progress Measurement Framework - Methodology', 2017, Geneva, available at https://www.un-page.org/files/public/gep_methodology.pdf, accessed January 202020.

PAGE, 'Green Industry Progress Index for 18 Chinese Provinces', 2019, Geneva, available at https://www.un-page.org/files/public/green_industry_progress_index_for_18_chinese_provinces.pdf, accessed January 202020.

Pérez, C. J., M. Niklitschek, M. Otárola and R. Madrigal, 'Bienes y Servicios Ambientales: Mercados no Tradicionales, Mecanismos de Financiamiento y Buenas Prácticas en América Latina y el Caribe', Turrialba, Costa Rica, Inter-American Development Bank, 2006.

Perlack, B. and W. Hinds, 'Evaluation of the Barbados solar water heating experience', 2003, available at http://solardynamicsltd.com/wp-content/uploads/2010/07/SWHreport1-2.pdf, accessed April 302013.

Rabinovitch, J., 'Curitiba: Towards sustainable urban development', Environment and Urbanization, 4(2): 62-73, 1992.

Rabinovitch, J. and J. Leitman, 'Urban planning in Curitiba'. In: S.M. Wheeler and T. Beatley, ed., The Sustainable Urban Development Reader, 237-248, London, Routledge, 2004. 
Schwerin,A.,' Solar Market Study: Analysis of the Potential Market for Solar Energy in the Caribbean', Saint Lucia, Caribbean Renewable Energy Development Programme (CREDP), 2010.

Solar Dynamics, 'The financial benefits of solar hot water systems to Barbados', Presentation, 2010, available at http://solardynamicsltd.com/wp-content/uploads/2010/05/ SOLARSEPT12Presentation-Central-BankFinal.pdf, accessed August 202013.

Strange, T. and A. Bayley, 'Sustainable development: Linking economy, society, environment', Paris Organisation for Economic Co-Operation and Development (OECD), 2008, available at http://www.oecd-library.org/docserver/download/0108121e.pdf?expires= 1377044745\&idid\&accnameguest\&checksum6B802779B854B54F95E142EC02A7CBB4, accessed May 302013.

Stuart, F., 'Launch of the government of Barbados-United Nations Environment Programme Partnership for a resource efficient green economy in Barbados and the undertaking of a green economy scoping study by the University of the West Indies, Cave Hill Campus, address', 2011, available at http://www.pnuma.org/documento/DISCURSO $\% 20$ PRIMER\%20MINISTRO\%20BARBADOS.pdf, accessed August 202013.

The Guardian, 'Is the Caribbean a paradise for renewable energy?', 2015, available at https:// www.theguardian.com/global-development-professionals-network/2015/aug/06/ caribbean-paradise-for-renewable-energy, accessed January 202020.

United Nations, 'The future we want', Outcome of the United Nations Conference on Sustainable Development. Rio de Jaineiro, Brazil, 20-22 June 2012, available at http:// www.uncsd2012.org/content/documents/727The\%20Future\%20We\%20Want $\% 20$ 19\%20June\%201230pm.pdf, accessed May 102013.

United Nations Environment Programme (UNEP) , 'Green Economy: Developing Countries Success Stories', Nairobi, 2010, available at http://www.unep.org/pdf/GreenEconomy_ SuccessStories.pdf, accessed August 102013.

UNEP, 'Green Economy Report: Pathways to Sustainable Development and Poverty Eradication', Nairobi, 2011, available at http://www.unep.org/greeneconomy/Portals/88/documents/ ger/ger_final_dec_2011/Green\%20EconomyReport_Final_Dec2011.pdf, accessed August 102013.

UNEP, 'Measuring Progress Towards a Green Economy', Nairobi, 2012, available at http://www. unep.org/greeneconomy/Portals/88/documents/research_products/MeasuringProgress. pdf, accessed August 102013.

Villatoro, P. and J.C. Feres, 'A System of Indicators for Monitoring Social Cohesion in Latin America', Santiago, Chile, Economic Commission for Latin America and the Caribbean (ECLAC), 2007, available at http://www.eclac.cl/publicaciones/xml/1/33911/LCG2362i.pdf, accessed August 102013.

Weiss, W. and F. Mauthner, 'Solar Heat Worldwide: Markets and Contribution to the Energy supply 2009', Paris, France, International Energy Agency (IEA), 2011, available at http:// www.cansia.ca/sites/default/files/policy_and_research/2009_iea_solarheatworldwide. pdf, accessed August 102013.

World Bank, Preparation Grant Agreement for Readiness Plan Readiness Fund of the FCPF Grant No. TF094486, 2009, available at https://forestcarbonpartnership.org/ sites/forestcarbonpartnership.org/files/Documents/PDF/Nov2009/Costa_Rica_ FCPF_R-PP_Formulation_Grant_Agreement.pdf, accessed August 232013.

WorldBank,Eco2 Cities:EcologicalCitiesas Economic Cities,Washington,DC,2010,availableathttp:// siteresources.worldbank.org/INTURBANDEVELOPMENT/Resources/3363871270074782769/Eco2_Cities_Book.pdf, accessed August 232013. 